[2] Zahrebelniy, V. O. (2015). The main aspects of the evaluation of microbiological risk of food. Veterinary Biotechnology, 26, 83-89.

[3] Afroz, H., Ahmed, T., Uddin, M. A. (2016). Microbiological analysis and antibacterial activity of pear samples. Stamford Journal of Microbiology, 5 (1), 1-4. doi: 10.3329/sjm.v5i1.26910

[4] Korzun, V. N., Tikhonenko, Yu. S. (2010). Functional products and their role in human nutrition. Scientific works ONACHT, 2 (38), 173-178.

[5] Serdyuk, M., Stepanenko, D., Baiberova, S., Gaprindashvili, N., Kulik, A. (2016). Substantiaton of selecting the method of pre-cooling of fruits. Eastern-European Journal of Enterprise Technologies, 4 (11 (82)), 62-68. doi: 10.15587/1729-4061.2016.76235

[6] Fatema, N., Acharjee, M., Noor, R. (2013). Microbiological Profiling of Imported Apples and Demonstration of Bacterial Survival Capacity through in vitro Challenge Test. American Journal of Microbiological Research, 1 (4), 98-104. doi: 10.12691/ajmr-1-4-6

[7] Odarchenko, A. M., Pogozhykh, M. I., Odarchenko, D. M. (2006). Pat. No. 13953 UA. Device to determine the amount of free and bound water at temperatures close to the temperature of liquid nitrogen. MPK A23L 1/00. No. u200511091; declareted: 23.11.2005; published: 17.04.2006, Bul. No. 4.

[8] Cherevko, O., Odarchenko, A., Pogozhikh, N., Odarchenko, D., Sokolova, E. (2016). Effect of sautéing of onion on its storage at low temperatures. Eastern-European Journal of Enterprise Technologies, 5 (11 (83)), 46-50. doi: 10.15587/1729-4061.2016.81391

[9] GOST 10444.15-19. Food products. Methods for determining the amount of mesophilic aerobic and facultative-anaerobic microorganisms (1994). Moscow: Publishing Standards, 13.

[10] GOST 30518. Food products. Methods for detecting and determining the number of bacteria of the group of E. coli bacteria (coliform bacteria) (2005). Moscow: Publishing Standards, 8 .

[11] GOST 30519. Food products. Methods for the detection of bacteria of the genus Salmonella (2005). Moscow: Publishing Standards, 10.

[12] GOST 10444.12-88. Food products. Methods for the determination of yeasts and molds (2010). Moscow: Standartinform Publishing, 8.

[13] DSTU 6029:2008. Fruit and berry semi-finished products (crushed and mashed potatoes) quick-frozen (2009). Kyiv: Derzhspozhyvstandart of Ukraine, 18.

\title{
INVESTIGATION OF THE MOISTURE-RETAINING POWER OF RYE-WHEAT GLUTEN AND FLOUR WITH POLYFUNCTIONAL FOOD SUPPLEMENT "MAGNETOFOOD"
}

\author{
Iryna Tsykhanovska \\ Department of food and chemical technologies \\ Ukrainian Engineering-Pedagogics Academy \\ 16 Universitetska str., Kharkiv, Ukraine, 61003 \\ cikhanovskaja@rambler.ru \\ Victoria Evlash \\ Department of Chemistry, Microbiology and Food Hygiene \\ Kharkiv State University of Nutrition and Trade \\ 333 Klochkivska str., Kharkiv, Ukraine, 61051 \\ evlashvv@gmail.com \\ Alexandr Alexandrov \\ Department of food and chemical technologies \\ Ukrainian Engineering-Pedagogics Academy \\ 16 Universitetska str., Kharkiv, Ukraine, 61003 \\ alexandrov.a.v.a.v@gmail.com
}




\section{Tetiana Lazareva}

Department of food and chemical technologies

Ukrainian Engineering-Pedagogics Academy

16 Universitetska str., Kharkiv, Ukraine, 61003

Lazareva_T.A@ukr.net

Karina Svidlo

Department of Technology and Restaurant Business Organization

Kharkiv Trade and Economic Institute of Kiev National Trade and Economic University of Ukraine

8 O. Yarosha lane, Kharkiv, Ukraine, 61045

karinasvidlo@rambler.ru

Tatyana Gontar

Department of food and chemical technologies

Ukrainian Engineering-Pedagogics Academy

16 Universitetska str., Kharkiv, Ukraine, 61003

taty-gontar@ukr.net

Liubov Yurchenko

Department of Social and Humanitarian Disciplines

National University of Civil Defense of Ukraine

96 Chernyshevsky str., Kharkiv, Ukraine, 61002

7733153@ukr.net

Larisa Pavlotska

Department of Chemistry, Microbiology and Food Hygiene

Kharkiv State University of Nutrition and Trade

333 Klochkivska str., Kharkiv, Ukraine, 61051

chem_mikvo@hduht.edu.ua

\footnotetext{
Abstract

The moisture-retaining power (WRP) of dough is one of main functional technological parameters, because it influences the output, structural-mechanical properties and quality characteristics of bread and bakery products. For increasing WRP of rye-wheat dough, the polyfunctional food supplement "Magnetofood" is offered. For determining, what component of rye-wheat dough plays the leading role in absorbing and retaining water - there was studied the influence of the polyfunctional food supplement "Magnetofood" on water-absorbing and water retaining power of rye-wheat gluten and rye-wheat flour. It was established, that adding the food supplement "Magnetofood" in amount $0,15 \%$ for the mass of rye-wheat gluten and rye-wheat flour increases their water-retaining power by $2,0 \%$ and by $2,5 \%$ respectively. There were studied water binding forms in gluten and flour at implementing the food supplement "Magnetofood" by the indicator method and one of differential-thermal analysis (DTA). There were established the quantity ratios of free and bound moisture in gluten and flour with food supplement "Magnetofood". It was established, that model systems, based on rye-wheat gluten and rye-wheat flour, enriched with "Magnetofood" supplement, demonstrate the increase of the amount of free and bound moisture in 1,3 and in 0,35 times in experimental samples of model systems based on gluten, respectively; in 1,2 and 0,29 times in experimental samples of model systems, based on flour, respectively.

DTA method established the increase of the total content of adsorptively and osmotically bound moisture in experimental samples of model systems based on rye-wheat gluten and rye-wheat flour at adding the food supplement "Magnetofood":

- adsorptively bound moisture grows: from $15,3 \%$ to $19,7 \%$ (samples of model systems based on rye-wheat gluten) and from $18,3 \%$ to $25,4 \%$ (for samples of model systems based on rye-wheat flour);

- osmotically bond water grows: from $10,3 \%$ to $14,4 \%$ (for samples of model systems based on rye-wheat gluten) and for $14,5 \%$ to $17,0 \%$ (for samples of model systems based on rye-wheat flour).

It was revealed, that the increase of the moisture-retaining power of rye-wheat gluten and rye-wheat flour, enriched with the food supplement "Magnetofood" is explained by the "cluster-loop-chain" model of hydration of gluten proteins at "Magnetofood" nanoparticles. The obtained experimental data may be used at elaborating the technology of rye-wheat bread, enriched with the
} 
polyfunctional food supplement "Magnetofood"; and also at elaborating innovative technologies of food systems with proteins as gliadin, glutenin and so on.

The results of this study have the theoretical and practical interest for the world scientific society, because they may be used for decelerating hardening processes, prolongation of storage terms, increase of output and improvement of quality parameters of bread and bakery products.

Keywords: polyfunctional food supplement "Magnetofood", rye-wheat gluten and flour, form of moisture bound, moisture-retaining power, indicator method, method of differential-thermal analysis, "cluster-loop-chain" model of proteins hydration.

\section{Introduction}

Food technologies use diverse food and bio-supplements, increasing the moisture-retaining power (MRP) of both raw materials and semi-products and also ready products. MRP increase favors the increase of the quality and output of ready products; decrease of their cost price [1-4].

Modern food technologies actively use biologically active substances of vegetable, fruit and herbal supplements [5-10] and also biocompounds of different chemical composition: soya, nut, enzymes, micro-water plants for increasing MRP [11-14].

For increasing the moisture-retaining power of flour and dough, mineral compounds (ammonium salts of orthophosphate acid, sodium and potassium orthophosphates) are used in bakery $[1,2]$.

Information sources [1-14] demonstrate the absence of data about polyfunctional food supplements of the complex action, and especially, nano-powder ones that increase the moisture-retaining power of both raw materials and semi-products and also ready products, made of them.

The revealed properties of the polyfunctional food supplement "Magnetofood" allow to recommend it for implementing in food systems, especially in rye-wheat gluten and flour. The aim of adding "Magnetofood" is to increase the moisture-retaining power of rye-wheat gluten and ryewheat flour. "Magnetofood" is a nano-powder with the large specific and active surface [15-18].

\section{Materials and Methods}

\section{1. Studied materials and equipment, used in the experiment}

The object of the research is the technology of rye-wheat bread.

The study of the influence of polyfunctional food supplement "Magnetofood" on the moisture-absorbing and moisture-retaining power (MRP) of rye-wheat gluten and flour was realized on the model systems:

- control sample 1 - dry rye-wheat gluten, received from rye-wheat flour, according to SSU-B 4583:2006. The ratio of rye peeled flour and wheat flour of the first sort is 60:40 according to the base recipe of rye-wheat bread "Darnitsky" [19]. At preparing control sample 1, dry ryewheat gluten was added with water in amount $0,16 \%$ of the mass of dry gluten. Then the mixture was accurately blended during 5-7 min;

- sample 2 - dry wheat-rye gluten with the polyfunctional food supplement "Magnetofood" in amount $0,15 \%$ of the gluten mass as powder [17]. Experimental sample 2 was prepared analogously to control sample 1, but the food supplement "Magnetofood" was implemented in the aforesaid amount;

- control sample 3 - raw rye-wheat gluten, received from rye-wheat flour, according to SSU-B 4583:2006. The ratio of rye peeled flour and wheat flour of the first sort is 60:40 according to the base recipe of rye-wheat bread "Darnitsky" [19];

- sample 4 - raw rye-wheat gluten with the polyfunctional food supplement "Magnetofood in amount $0,15 \%$ of the mass of raw gluten as powder [17]. Experimental sample 4 was prepared analogously to control sample 3, but the food supplement "Magnetofood" was implemented in the aforesaid amount and accurately blended during 5-7 $\mathrm{min}$;

- control sample 5 - rye-wheat flour according to SSU-B 4583:2006. The ratio of rye peeled flour and wheat flour of the first sort is 60:40 according to the base recipe of rye-wheat bread "Dar- 
nitsky" [19]. At preparing control sample 5, dry rye-wheat flour was added with water in amount $0,67 \%$ to the mass of dry flour. Then the mixture was accurately blended during $8-10 \mathrm{~min}$;

- sample 6 - wheat-rye flour with the polyfunctional food supplement "Magnetofood" in amount $0,15 \%$ of the gluten mass as powder [17]. Experimental sample 6 was prepared analogously to control sample 5, but the food supplement "Magnetofood" was implemented in the aforesaid amount.

Fig. 1 presents the experimental samples of rye-wheat gluten, Fig. $\mathbf{2}$ - the experimental samples of rye-wheat flour.

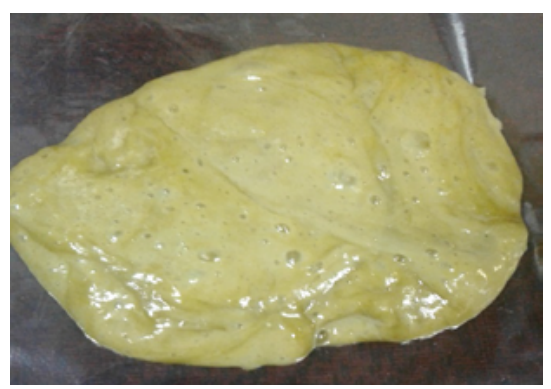

$a$

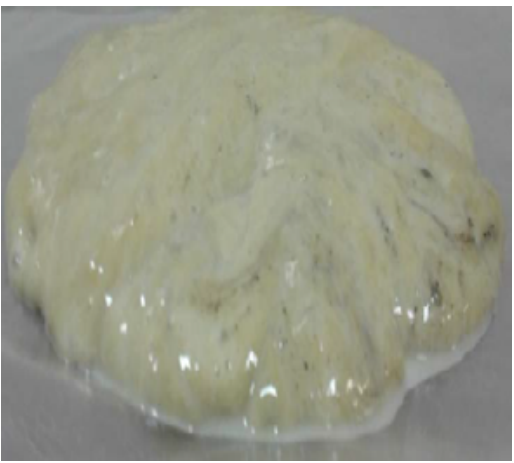

c

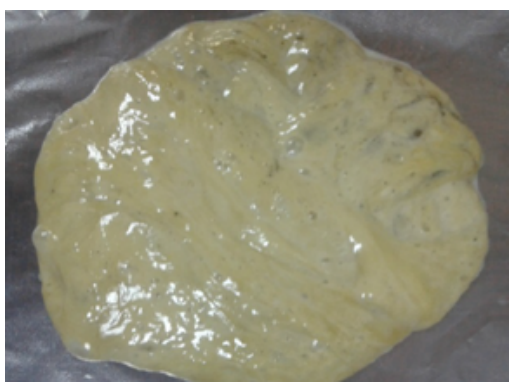

$b$

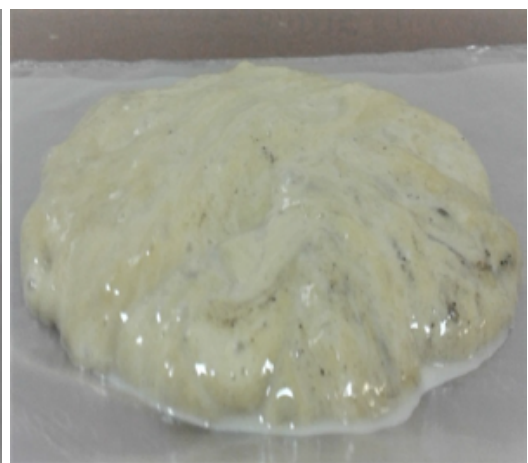

$d$

Fig. 1. The experimental samples of rye-wheat gluten: $a$-sample $1 ; b$-sample $2 ; c$-sample $3 ; d$-sample 4

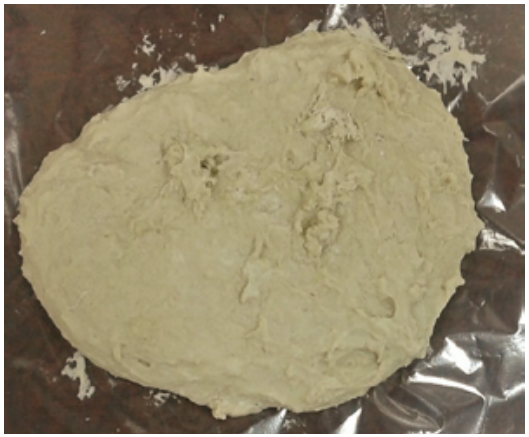

a

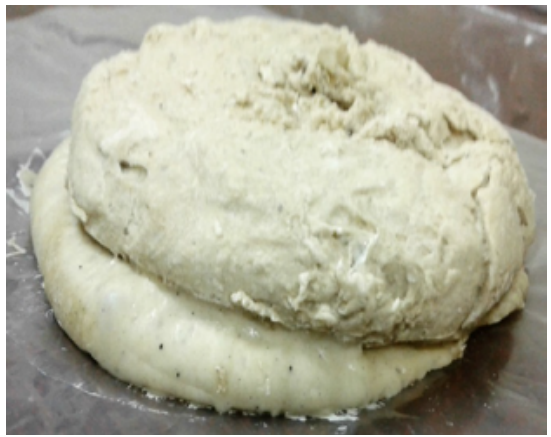

b

Fig. 2. The experimental samples of rye-wheat flour: $\boldsymbol{a}$-sample $5 ; b$-sample 6

The mass of gluten and flour was determined on the electric analytic scales of ANG series (Ukraine), humidity of gluten and flour was determined by the gravimetric method using the thermal chamber UF55 Memmert (Germany) and apparatus AUSIFI-CV (Ukraine). The concentration of the saccharose solution - on the laboratory refractometer IRF-454B2M (Russia). DTA was realized on the derivatograph Q1500D («Paulik - Erdey» - Hungry. Microscopy on the monocular microscope Micromed 1var 1 - 20 (Russia). 
Fig. 3 presents devices, used for studying physical-chemical characteristics of the experimental samples of rye-wheat gluten and rye-wheat flour.

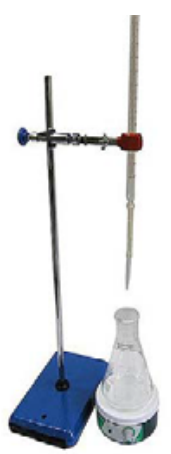

$a$

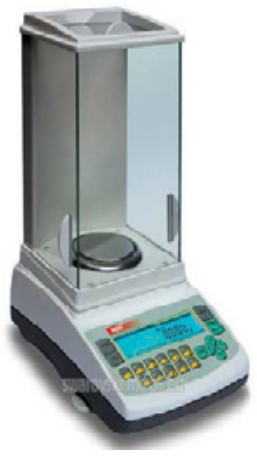

$b$

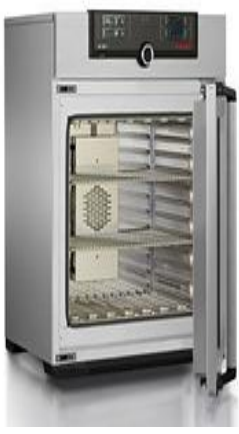

C

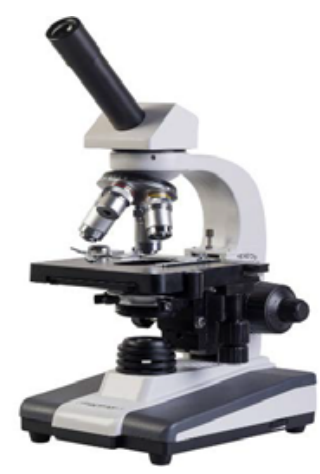

$d$
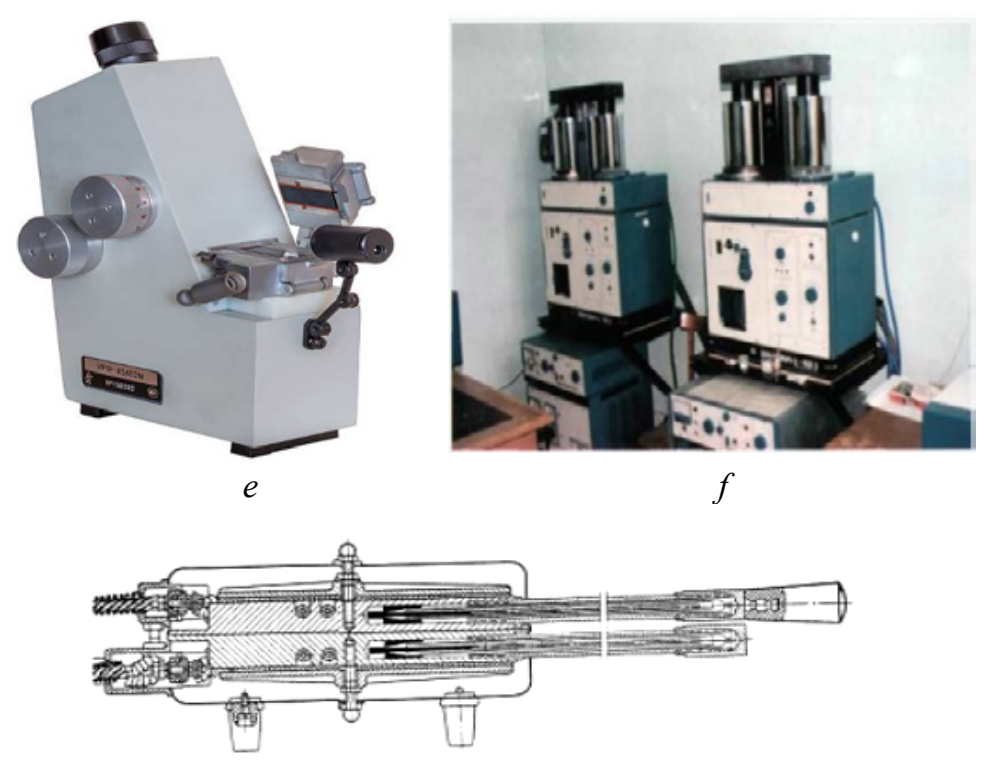

$g$

Fig. 3. The devices, used for studying parameters of dough and bread: $a$ - hand device for titration; $b$ - electronic analytic scales ANG; $c$ - thermal chamber UF55 Memmert; $d$ - monocular microscope Micromed 1 var $1-20 ; e$ - laboratory refractometer IRF-B; $f$-derivatograph Q1500D (Paulik - Erdey); $g$ - device ARDIBMI-MM

\section{2. Methods of determining organoleptic, physical-chemical and technological pa-} rameters

The standard research methods, considered below [20-25] and SSU-B 4583:2006 were used at the study.

The determination of humidity was made according to the standard accelerated method according to SSU-P 4583:2006. Its essence is in drying the batch of the experimental sample of rye-wheat gluten or flour at a certain temperature and determination of humidity [21-23].

Determination of humidity of gluten and flour. Humidity of $\mathrm{W}_{\mathrm{gl}(\mathrm{f})}$ was determined just after blending (and also after keeping the experimental samples in the thermal chamber at $20{ }^{\circ} \mathrm{C}$ during 6 hours, 12 hours, 18 hours, 24 hours, 36 hours, 72 hours) by the express method of drying at temperature $160{ }^{\circ} \mathrm{C}$ on ARDIBMI-MM by following methodology [20-23]: two batches of the experimental sample of gluten or flour in $5 \mathrm{~g}$ are weighed on the analytic scales with exactness up to $0,001 \mathrm{~g}$. These batches are dried on ARDIBMI-MM during 5 minutes, cool in the dessicator during 1-2 minutes. After that they are weighted on the analytic scales again with exactness $0,001 \mathrm{~g}$. $\mathrm{W}_{\mathrm{gl}(\mathrm{fl})}$ 
is calculated by the difference in gluten or flour mass before and after their drying (by the dry residue) by formula (1):

$$
\mathrm{W}_{\mathrm{gl}(\mathrm{fl})}=\left(\mathrm{M}_{1}-\mathrm{M}_{2}\right) / \mathrm{M}_{1} \cdot 100 \%
$$

where $\mathrm{W}_{\mathrm{gl}(\mathrm{fl})}$ - humidity of gluten or flour, \%; $\mathrm{M}_{1}$ - mass of batch of gluten or flour before drying, $\mathrm{g}$; $\mathrm{M}_{2}$ - mass of batch of gluten or flour before drying, $\mathrm{g}$.

Determination of moisture-retaining power of gluten and flour by the method, based on a certain amount of water [21, 22]. Gluten or flour is put in a dish up to the top, smoothed, and a hollow is made in the middle of it by a spoon or spatula. Then the certain amount of usual water $\left(10\right.$ or $20 \mathrm{~cm}^{3}$ ) is measured by a pipette and blended with gluten or flour by the spatula, then the dough system is pressed by the hands. Blending is finished, when the dough system acquires the required consistence. After that it is weighed, and water amount, bound by $1100 \mathrm{~g}$ of gluten or flour is calculated. The moisture-retaining power $(\mathrm{X})$ is calculated by formula (2):

$$
X=100 \cdot a /(b-a)
$$

where $\mathrm{X}$ - moisture-retaining power (MRP) of gluten or flour, $\%$; a - amount of usual water, $\mathrm{cm}^{3}$; $\mathrm{b}-$ mass of gluten or flour, $\mathrm{g}$.

At studying MRP of dry gluten and flour, the experimental samples of the first blending and $\mathrm{X}$ determination, $\%$ were kept in the thermal chamber at $20{ }^{\circ} \mathrm{C}$ during 6 hours 12 hours, 18 hours, 24 hours, 36 hours, 72 hours. Then their mass was determined on the analytic scales with exactness up to $0,01 \mathrm{~g}$. The moisture-retaining power (X) was calculated by formula (3):

$$
\mathrm{X}=100 \cdot \mathrm{a} / \mathrm{b}
$$

where $\mathrm{X}$ - moisture-retaining power (MRP) of gluten or flour, \%; a - mass of the dough system of gluten of flour with water after storage, $\mathrm{g} ; \mathrm{b}$ - initial mass of gluten or flour, $\mathrm{g}$.

Determination of hydration power (HP) or gluten hydration [21 -23] at storage was realized on the studied samples of raw gluten, kept in the thermal chamber at $20{ }^{\circ} \mathrm{C}$ during 6 hours 12 hours, 18 hours, 24 hours, 36 hours, 72 hours. Then their mass was determined on the analytic scales with exactness up to $0,01 \mathrm{~g}$. For determining the amount of raw gluten, it was dried and weighed. Drying was realized in the drying camber during 1 hour at temperature $60-70^{\circ} \mathrm{C}$, then 2 hours more at temperature $120^{\circ} \mathrm{C}$ up to the constant mass. Hydration power (HP) was calculated by formula (4):

$$
\mathrm{HP}=100 \cdot\left(\mathrm{m}_{2}-\mathrm{m}_{1}\right) / \mathrm{m}_{1}
$$

where $\mathrm{HP}$ - hydration power of raw gluten, $\% ; \mathrm{m}_{2}$ - mass of raw gluten, $\mathrm{g} ; \mathrm{m}_{1}$ - mass of dry gluten, $\mathrm{g}$.

The mass share of bound and free moisture was determined by the indicator method [26] and one of differential-thermal analysis (DTA) [27].

According to M. I. Knyagenichev's method [26] the batch of the studied sample of gluten or flour in amount $4 \mathrm{~g}$ was kept during $5 \mathrm{~min}$ with $20 \mathrm{~cm}^{3}$ of $10 \%$ solution of saccharose. The calculation of bound moisture is conducted by formula (5):

$$
\mathrm{X}=\mathrm{B} \cdot\left(\mathrm{b}_{2}-\mathrm{b}_{1}\right) / \mathrm{P} \cdot \mathrm{b}_{2}
$$

where $\mathrm{X}$ - amount of bound moisture, $\mathrm{g}$ for $1 \mathrm{~g}$ of dry substance (DS); $\mathrm{b}_{1}$ and $\mathrm{b}_{2}$ - initial and output concentrations of saccharose solution, $\%$; B - mass of $20 \mathrm{~cm}^{3} 10 \%$ saccharose solution, $\mathrm{g} ; \mathrm{P}-\mathrm{batch}$ of dry substance (DS), g.

According to A. I. Ermakov's methodology [26] the batch of the experimental sample of gluten or flour in amount $5 \mathrm{~g}$ is placed in a flask with $15 \mathrm{~cm}^{3}$ of $60 \%$ saccharose solution. After 5 min keeping, it is filtered and its concentration is measured on the refractometer IRF-454B2M. The results of determination are used for calculating free water by formula (6): 


$$
\mathrm{Y}=\left(\mathrm{C}_{0}-\mathrm{C}_{1}\right) \cdot \mathrm{m} \cdot 100 / \mathrm{C}_{1} \cdot \mathrm{g} \cdot \mathrm{W}
$$

where $\mathrm{Y}$ - content of free water, $\%$ of the total content; $\mathrm{C}_{0}$ - initial concentration of saccharose solution, $\% ; \mathrm{C}_{1}-$ Final concentration of saccharose solution, $\% ; \mathrm{m}-$ mass of output saccharose solution, $\mathrm{g}$; $\mathrm{g}$ - batch of the experimental sample of gluten or flour, $\mathrm{g}$; $\mathrm{W}$ - total content of water in $1 \mathrm{~g}$ of the experimental sample of gluten or flour, $g$.

For DTA, there was used the derivatograph Q1500D (Paulik - Erdey). The studies were conducted in quartz melting pots with batch mass $1 \mathrm{~g}$. $\mathrm{Al}_{2} \mathrm{O}_{3}$, fried to $1773 \mathrm{~K}$ was used as an etalon. Samples were heated to $473 \mathrm{~K}$ with heating speed $3 \mathrm{~K} / \mathrm{min}$. [27].

Microscopy of the experimental samples was realized on the monocular microscope Micromed 1 var 1 - 20 [27]. Preparations for microscopy were prepared in the following way. The sample in amount 1-2 mg was placed on the subject glass, covered with the coating glass, accurately rubbed along the circle by a rubber. The sample was analyzed by the microscope (magnification 100).

\section{Results}

Research methods, considered in section 2 will have the practical use at studying functional-technological characteristics, especially, the moisture-absorbing and moisture-retaining power of gluten and flour.

Fig. 4, 5 present the influence of the food supplement "Magnetofood" on the moisture-retaining power (MRP) of dry rye-wheat gluten and flour in the experimental samples.

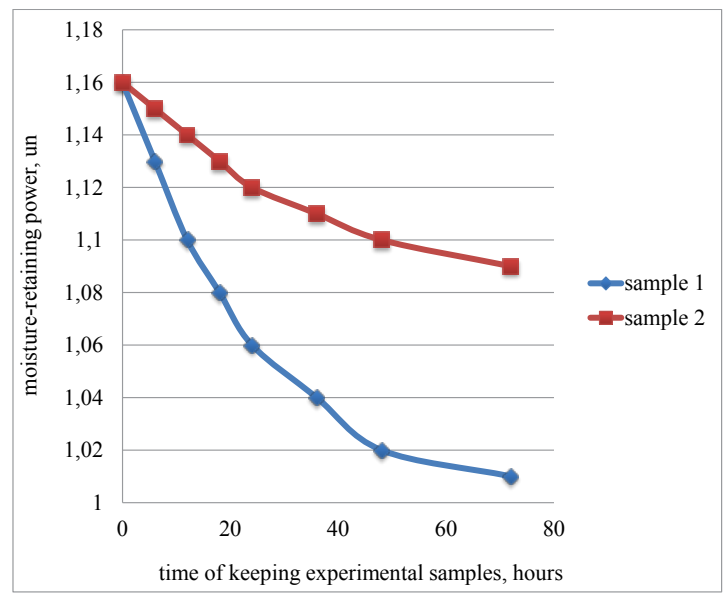

Fig. 4. influence of the food supplement "Magnetofood" on the moisture-retaining power of the experimental samples of dry rye-wheat gluten at storage

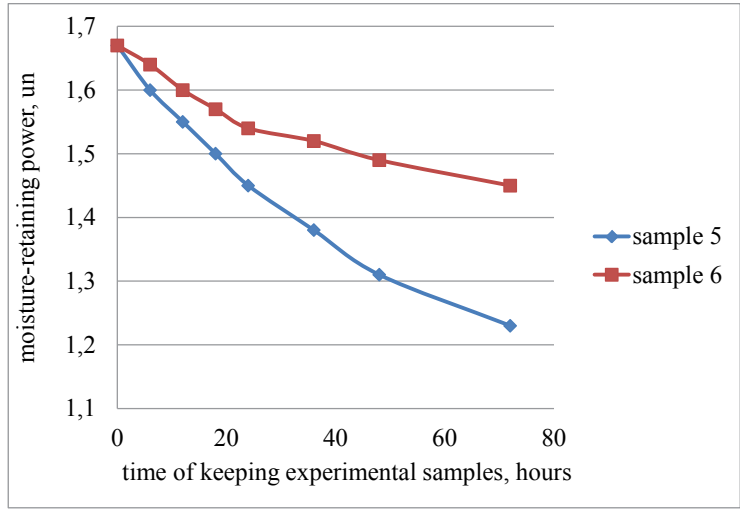

Fig. 5. influence of the food supplement "Magnetofood" on the moisture-retaining power of the experimental samples of dry rye-wheat flour at storage 
It was experimentally established (Fig. 4, 5), that implementing the polyfunctional food supplement "Magnetofood" in dry rye-wheat gluten and flour favors the increase of MRP of gluten and flour comparing with control samples (without "Magnetofood: by 4, $85 \%$ for the model system based on gluten and 10,2\% for the model system based on flour. It is connected with the fact that the food supplement "Magnetofood" is able to create hydrophilic associates with protein complexes of gluten.

Fig. 6, 7 and Table 1 present the results of differential-thermal and indicator methods of analyzing bound and free, sorption and physical-mechanical moisture in the experimental samples of dry rye-wheat gluten and flour.

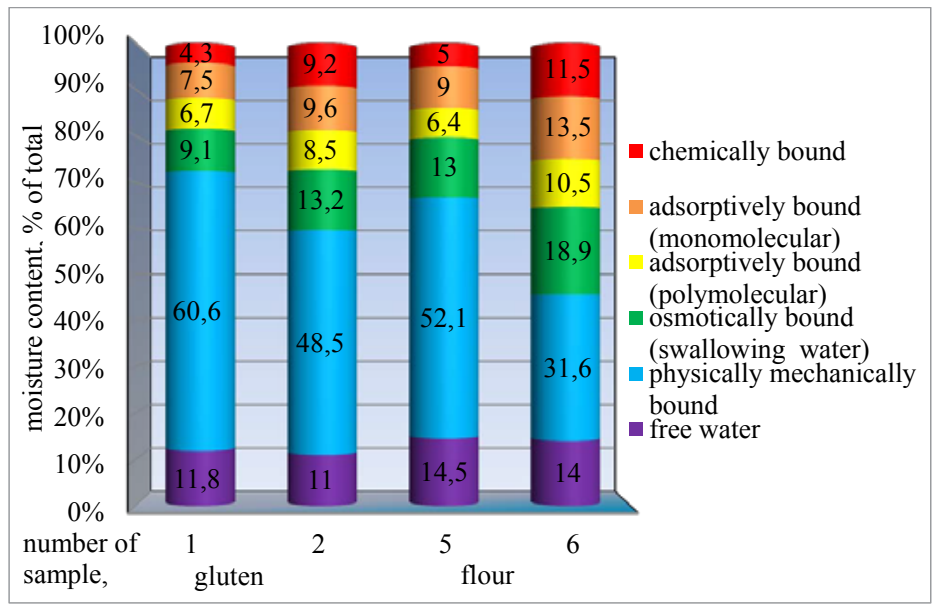

Fig. 6. Influence of the food supplement "Magnetofood" on the ratio of water of different binding forms of the experimental samples of dry rye-wheat gluten and flour at storage during 1 hour

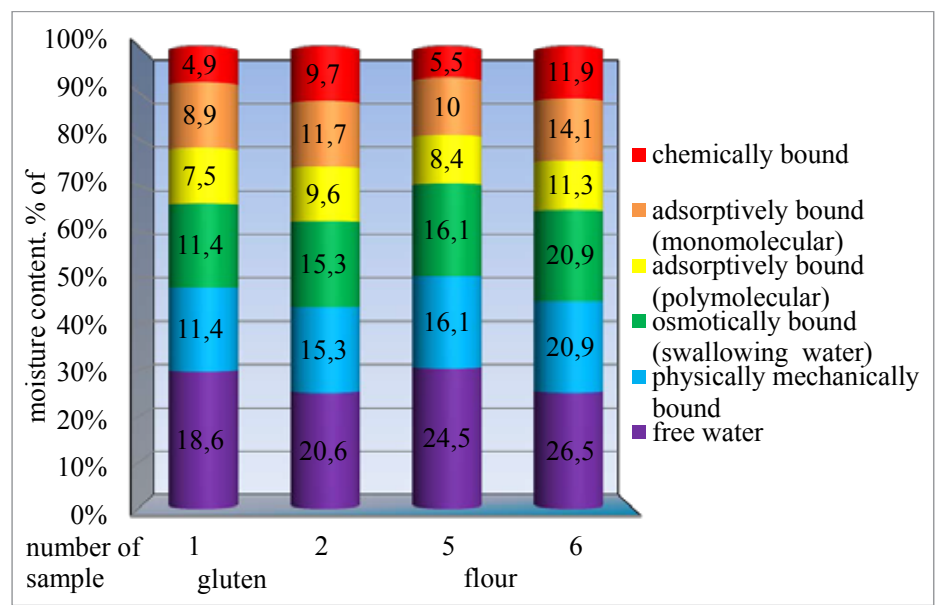

Fig. 7. Influence of the food supplement "Magnetofood" on the ratio of water of different binding forms of the experimental samples of dry rye-wheat gluten and flour at storage during 72 hours

The experimental data of Fig. 6, 7 prove the fact that the polyfunctional food supplement "Magnetofood" favors the increase of water-absorbing and water retaining power of rye-wheat gluten and rye-wheat flour.

According to the data of table 1,1/4 shares of the total amount of water in the experimental samples of dry rye-wheat gluten and flour are bound, and 3/4 shares are free, osmotic and physical-mechanical.

The research results confirm the important functional-technical property of the food supplement "Magnetofood" - moisture-retaining power.

The obtained experimental data may be used in the technology of rye-wheat bread, enriched with the food supplement "Magnetofood". 
Table 1

The influence of the food supplement "Magnetofood" on the ratio of bound and free, osmotic and physicalmechanical water of the experimental samples of dry rye-wheat gluten and flour at storage by the indicator method (IM) and one of differential-thermal analysis.

\begin{tabular}{|c|c|c|c|c|c|c|c|c|}
\hline \multirow{4}{*}{$\begin{array}{l}\text { Experimental } \\
\text { samples of glu- } \\
\text { ten and flour }\end{array}$} & \multicolumn{4}{|c|}{ Amount of free, osmotic and physical-mechanical moisture, $\%$} & \multicolumn{4}{|c|}{ Amount of bound moisture, \% } \\
\hline & \multicolumn{8}{|c|}{ Storage duration, hours } \\
\hline & \multicolumn{2}{|c|}{1} & \multicolumn{2}{|c|}{72} & \multicolumn{2}{|c|}{1} & \multicolumn{2}{|c|}{72} \\
\hline & IM & DTA & IM & DTA & IM & DTA & IM & DTA \\
\hline $\begin{array}{c}\text { Sample } 1 \\
\text { Control }\end{array}$ & $78,7 \pm 0,5$ & $77,0 \pm 0,2$ & $72,7 \pm 0,5$ & $71,0 \pm 0,2$ & $21,3 \pm 0,5$ & $23,0 \pm 0,2$ & $27,3 \pm 0,5$ & $29,0 \pm 0,2$ \\
\hline Sample 2 & $69,0 \pm 0,5$ & $68,0 \pm 0,2$ & $72,7 \pm 0,5$ & $71,2 \pm 0,2$ & $31,0 \pm 0,5$ & $32,0 \pm 0,2$ & $27,3 \pm 0,5$ & $28,8 \pm 0,2$ \\
\hline $\begin{array}{c}\text { Sample } 5 \\
\text { Control }\end{array}$ & $76,1 \pm 0,5$ & $75,1 \pm 0,2$ & $79,6 \pm 0,5$ & $78,1 \pm 0,2$ & $23,9 \pm 0,5$ & $24,9 \pm 0,2$ & $20,4 \pm 0,5$ & $21,9 \pm 0,2$ \\
\hline Sample 6 & $62,7 \pm 0,5$ & $61,5 \pm 0,2$ & $64,5 \pm 0,5$ & $63,2 \pm 0,2$ & $37,3 \pm 0,5$ & $38,5 \pm 0,2$ & $35,5 \pm 0,5$ & $36,8 \pm 0,2$ \\
\hline
\end{tabular}

\section{Conclusions}

The research methods of flour, gluten and model systems, based on them, presented in the work, may be used at studying the influence of diverse supplements, improvers, technological holds and so on functional-technological characteristics, especially moisture-retaining power of wheatrye dough and bread of it.

Using the considered methodologies, scientists can study the influence of diverse complex food supplements on humidity, water-absorbing and water-retaining power of model systems, based on gluten and flour and also ready products in future; to study the amount of bound and free moisture in diverse dough semi-products more detail.

The shortcoming of this work is the fact that the effect of the offered methods was considered only on one type of model systems - rye-wheat and the influence of only one food supplement - polyfunctional food supplement "Magnetofood" on the given model system was studied. It is also unknown, how this supplement influences technological parameters of dough of another recipe composition (of different types and sorts of flour).

The positive side is the fact that the research methods, offered in the work, may be used for studying functional-technological characteristics, especially moisture-retaining ability of not only rye-wheat dough and ready products, but also rye, wheat and so on.

At the same time, the research results may be used in the technology of rye-wheat bread with adding the polyfunctional food supplement "Magnetofood".

\section{References}

[1] Buldakov, A. (2008). Pishchevye dobavki. Moscow: SPb., 280.

[2] Matveeva, I. V., Velitskaya, I. G. (1998). Pishhevye dobavki i khlebopekarnye uluchshiteli v proizvodstve khleba. Novosibirsk: Sibir univ. izd-vo, 328.

[3] Kolpakova, V. V., Studennikova, O. Yu. (2009). Gidratatsionnaya sposobnost' i fiziko-khimicheskie svoystva belkov pshenichnoy kleykoviny. Izvestiya vuzov. Pishhevaya tekhnologiya, 2-3, 5-8.

[4] Auerman, L. Ya.; Puchkova, L. I. (Ed.) (2003). Tekhnologiya khlebopekarnogo proizvodstva. Saint Petersburg: Professiya, 253.

[5] Chugunova, O. V., Pastushkova, E. V. (2015). Modeling of organoleptic indicators of bread with plant supplements. Bulletin of the South Ural State University. Series Food and Biotechnology, 3 (4), 80-87. doi: 10.14529/food 150411

[6] Tamazova, S. U., Lisovoy, V. V., Pershakova, T. V., Kasimirova, M. A. (2016). Food supplements based on vegetable raw materials in the production of baked goods and pastries. Polythematic Online Scientific Journal of Kuban State Agrarian University, 122 (8). doi: 10.21515/1990-4665-122-076

[7] Roslyakov, Yu. F., Vershinina, O. L., Gonchar, V. V. (2016). Nauchnye razrabotki dlya hlebopekarnoy i konditerskoy otrasley. Tekhnologii pishchevoy i pererabatyvayushchey promyshlennosti APK-produkty zdorovogo pitaniya, 6, 42-47.

[8] Roslyakov, Yu. F., Vershinina, O. L., Gonchar, V. V. (2010). Perspektivnye issledovaniya tekhnologiy hlebobulochnyh izdeliy funktsional'nogo naznacheniya. Izvestiya vuzov. Pishchevaya tekhnologiya, 1, 123-125. 
[9] Filips, G. O., Vil'yams, P. A., Kochetkova, A. A., Sarafanova, L. A. (Eds.) (2006). Spravochnik po gidrokolloidam. Saint Petersburg: GIORD, 536.

[10] Tsitrusovye volokna Herbacel AQ Plus - tip N: spetsifikatsii dlya pishhevykh dobavok i retseptury (2013). Available at: http://specin.ru

[11] Ngemakwe, P. N., Le Roes-Hill, M., Jideani, V. (2014). Advances in gluten-free bread technology. Food Science and Technology International, 21 (4), 256-276. doi: 10.1177/1082013214531425

[12] Bird, L. G., Pilkington, C. L., Saputra, A., Serventi, L. (2017). Products of chickpea processing as texture improvers in gluten-free bread. Food Science and Technology International, 23 (8), 690-698. doi: $10.1177 / 1082013217717802$

[13] Garcia-Segovia, P., Pagan-Moreno, M. J., Lara, I. F., Martinez-Monzo, J. (2017). Effect of microalgae incorporation on physicochemical and textural properties in wheat bread formulation. Food Science and Technology International, 23 (5), 437-447. doi: 10.1177/1082013217700259

[14] Boubaker, M., Omri, A. E., Blecker, C., Bouzouita, N. (2016). Fibre concentrate from artichoke (Cynara scolymus L.) stem by-products: Characterization and application as a bakery product ingredient. Food Science and Technology International, 22 (8), 759-768. doi: 10.1177/1082013216654598

[15] Tsykhanovska, I., Evlash, V., Alexandrov, A., Svidlo, K., Gontar, T. (2017). Influence of the polyfunctional food supplement "Magnetofood" on the quality of the wheat-rye bread "Kharkiv Rodnichok" in the storage process. Eastern-European Journal of Enterprise Technologies, 5 (11 (89)), 61-70. doi: 10.15587/1729-4061.2017.111522

[16] Tsykhanovska, I., Evlash, V., Alexandrov, A., Svidlo, K., Gontar, T. (2017). Research quality of the wheat-rye bread with addition of the polyfunctional food supplement «Magnetofood». EUREKA: Life Sciences, 5, 45-52. doi: 10.21303/2504-5695.2017.00431

[17] Tsykhanovska, I., Evlash, V., Alexandrov, A., Lazareva, T., Svidlo, K., Gontar, T. (2017). Design of technology for the rey-wheat bread "Kharkivski rodnichok" with the addition of polyfunctional food additive "Magnetofood". Eastern-European Journal of Enterprise Technologies, 6 (11 (90)), 48-58. doi: $10.15587 / 1729-4061.2017 .117279$

[18] Tsykhanovska, I., Evlash, V., Alexandrov, A., Lazareva, T., Svidlo, K., Gontar, T. (2017). Research into technological indicators of a rye-wheat dough semi-finished product with the addition of the polyfunctional food supplement “Magnetofood." EUREKA: Life Sciences, 6, 43-50. doi: 10.21303/2504-5695.2017.00511

[19] Ershov, P. S. (2004). Sbornik retseptur na hleb i hlebobulochnye izdeliya. Saint Petersburg: Profi-inform, 190.

[20] Lichko, N. M.; Lichko, N. M. (Ed.) (2000). Tekhnologiya hlebopekarnogo proizvodstva. Moscow: Kolos, 552 .

[21] Namestnikov, A. F. (1974). Metody analiza pishhevykh sel'skokhozyaystvennykh produktov i meditsinskikh preparatov. Moscow: Pishhevaya promyshenost', 743.

[22] Koryachkina, S. Ya., Berezina, N. A., Khmeleva, E. V. (2010). Metody issledovaniya kachestva khlebobulochnykh izdeliy. Orel: OrelGTU, 166.

[23] Kasymova, Ch. K. (2012). Laboratornyy praktikum po kursu «Tekhnologiya khleba, konditerskikh i makaronnykh izdeliy». Bishkek: Kyrgyzskiy gosudarstvennyy tekhnicheskiy universitet im. I. Razzakova, 48.

[24] Romanov, A. S., Davydenko, N. I., Shatnyuk, L. N., Matveeva, I. V., Poznyakovskiy, V. M.; Poznyakovskiy, V. M. (Ed.) (2005). Ekspertiza khleba i khlebobulochnykh izdeliy, kachestvo i bezopasnost'. Novosibirsk: Sib. univ. iz-vo, 278.

[25] Botasheva, Kh. Yu. (2013). Tekhnologiya proizvodstva khlebobulochnykh izdeliy. Cherkessk: BITS SevKavGGTA, 43.

[26] Yurchak, V. G., Berzina, N. I., Shmarovoz, V. M., Prishhepa, M. P. (1989). Opredelenie svyazannoy vody indikatornym metodom v khlebopekarnom proizvodstve. Izvestiya Vuzov. Pishhevaya tekhnologiya, 4, 78-80.

[27] Nilova, L. P., Kalinina, I. V., Naumenko N. V. (2013). Metod differentsial'no-termicheskogo analiza v otsenke kachestva pishhevykh produktov. Vestnik YUUrGU. Seriya «Pishhevye i biotekhnologii», 1 (1), 43-49.

[28] Aleksandrov, O. V., Tsykhanovska, I. V., Lazarieva, T. A., Pavlotska, L. F., Hontar, T. B.; Yevlash, V. V., Potapov, V. O., Radchenko, M. I., Savytska, N. L. (Eds.) (2016). Vykorystannia zhyro-mahnetytovoi suspenzii dlia pidvyshchennia kharchovoi tsinnosti tsukerok «Sukhofrukty v shokoladi», zbahachenykh zalizovmisnoiu kharchovoiu dobavkoiu. Povnotsenne kharchuvannia: innovatsiini aspekty tekhnolohii, enerhoefektyvnoho vyrobnytstva, zberihannia ta marketynhu. Kharkiv: Svit knyh, 143-170. 